\title{
Suppression of Soilborne Diseases of Soybean With Cover Crops
}

\author{
L. Wen, Department of Crop Sciences, University of Illinois, Urbana, 61801; S. Lee-Marzano, Department of Biology \& Microbiology and \\ Department of Plant Science, South Dakota State University, Brookings, 57007; L. M. Ortiz-Ribbing, Dept. of Ag and Life Science, University of \\ Wisconsin-Extension, Madison, 53703; J. Gruver, School of Agriculture, Western Illinois University, Macomb, 61455; G. L. Hartman, United \\ States Department of Agriculture-Agriculture Research Service and Department of Crop Sciences, University of Illinois, Urbana, 61801; and D. M. \\ Eastburn, ${ }^{\dagger}$ Department of Crop Sciences, University of Illinois, Urbana, 61801
}

\begin{abstract}
Field trials were conducted from 2010 to 2013 at four locations in Illinois to evaluate the impact of cover crops (cereal rye [Secale cereal], brown mustard [Brassica juncea], winter canola [B. napus], and winter rapeseed [B. napus]) on soybean [Glycine $\max ]$ stands and yield, diseases, pathogen populations, and soil microbial communities. Cover crops were established in the fall each year and terminated the following spring either by using an herbicide (no-till farms), by incorporation (organic farm), or by an herbicide followed by incorporation (research farm). Although shifts

in soilborne pathogen populations and microbial community structure were not detected, cover crops were found to induce general soil suppressiveness in some circumstances. Cereal rye and rapeseed improved soybean stands in plots inoculated with Rhizoctonia solani and decreased levels of soybean cyst nematode in the soil. Cereal rye increased soil suppressiveness to $R$. solani and Fusarium virguliforme, as measured in greenhouse bioassays. Cereal rye significantly improved yield when Rhizoctonia root rot was a problem.
\end{abstract}

Soilborne diseases cause reduced plant growth, lower grain quality, and reduced marketable yield in soybean (Glycine max L.) production systems (Hartman et al. 2015). Fully resistant cultivars are not available for many of the soilborne diseases; therefore, management strategies rely primarily on the use of fungicides, seed treatments, and cultural practices. Reductions in pesticide use for economic, environmental, and resistance reasons necessitate additional disease management options.

The incorporation of cover crops into soybean/corn (Zea mays L.) production systems has well documented benefits, such as reduced soil erosion (Gómez et al. 2011), increased soil organic matter (Nascente et al. 2013), reduced nitrogen leaching (Kaspar et al. 2007; Mazzoncini et al. 2011), increased weed suppression (Davis 2010; Mirsky et al. 2011), and increased populations of beneficial insects (Bugg and Dutcher 1989). Furthermore, the use of cover crops to suppress disease is supported by studies showing the effective control of soybean cyst nematode on soybean by using cereal rye (Secale cereale L.) as a winter cover crop (Earl Creech et al. 2008; Riga et al. 2001).

Cover crops can foster the development of disease suppressive soils, and winter cover crops have been used for several decades in high-input vegetable and fruit production systems for the purpose of reducing soilborne diseases and weed pressure (Hoyt 1999; Masiunas et al. 1995; Ristaino et al. 1997), as well as providing soil conservation benefits. Small grain and Brassica cover crops were first reported to abate fungal (Ji et al. 2012; Larkin and Griffin 2007; Mowlick et al. 2013) and nematode problems (Buskov et al. 2002; Wang et al. 2001) during in vitro studies of various crops in the 1990s.

There is increasing interest in using cover crops in agronomic systems in the Midwestern U.S. for improving soil and crop health. Field studies have shown that the use of winter cover crops in a cornsoybean rotation system reduced soil compaction and weed pressure (Haramoto and Gallandt 2004; Krishnan et al. 1998; Moore et al. 1994), and increased soil carbon content (Villamil et al. 2006). However, information based on field studies in Midwestern U.S. soybean

${ }^{\dagger}$ Corresponding author: D. M. Eastburn; E-mail: eastburn@illinois.edu

*The $\boldsymbol{e}$-Xtra logo stands for "electronic extra" and indicates that two supplementary tables and one supplementary figure are published online.

Accepted for publication 21 June 2017.

() 2017 The American Phytopathological Society systems for pathogen control are limited, and sound management recommendations are needed for the Midwest, where more than $80 \%$ of U.S. soybeans are produced (USDA's National Agricultural Statistic Service for historical data on soybean and other oil crop acreage, yields, and prices).

Cover crops in the Brassicaceae family, such as brown mustard (Brassica juncea L.), winter canola (B. napus L.), and winter rapeseed (B. napus L.), are known to produce high levels of glucosinolates, which are enzymatically converted into allelochemicals, including isothiocyanates (ITCs) and related compounds, when incorporated into soil as green manure (Bangarwa et al. 2011; De Nicola et al. 2013; Szczygłowska et al. 2011). Allelochemical compounds produced during the degradation of plant materials share a similar mode of action for pathogen control as synthetic pesticides that are derivatives of ITCs. These compounds are toxic to a wide spectrum of organisms and act as bio-fumigants (Curto et al. 2016; Rudolph et al. 2015). In addition, studies have also shown that when used as green manure, Brassica cover crops are associated with changes in soil microbial community structure (Buyer et al. 2010; Carrera et al. 2007; Frasier et al. 2016; Mbuthia et al. 2015), sometimes increasing populations of known biological control agents in the rhizosphere (Benítez et al. 2007).

Incorporating cover crops as green manure is widely used to obtain the maximum disease suppressive benefit of the cover crops. Larkin and Halloran (2014) compared four application methods of cover crops on suppressing soilborne potato diseases and observed the best results for disease suppression when cover crops were used as a green manure.

In order for cover crops to be used more in Midwest cropping systems, they need to fit into conventional farming practices, such as notill systems. In many Midwest states, including Illinois, farmers use no-till and do not incorporate their cover crops. In no-till systems, it is common practice to terminate the cover crops in the spring using a burn-down herbicide such as glyphosate. When considering the impact of using a cover crop that might typically be incorporated as a green manure, it is important to remember that such incorporation cannot be done in no-till systems. Our experimental design and methods were developed to include evaluating soil suppressiveness in these cropping systems. Therefore, this research needed to explore three individual cropping systems and the potential or feasibility of building soil suppressiveness in each.

Previously, we implemented greenhouse assays to assess disease suppression of field soil in soybean (Marzano et al. 2015). Here, we used a similar approach to compare the efficacy of cover crops 
reported to inhibit multiple soilborne diseases simultaneously, and the use of cover crops to induce the development of disease suppressive soils. We focused on pathogens that can significantly reduce soybean yield including Rhizoctonia solani (the causal agent of Rhizoctonia root rot), Fusarium virguliforme, the causal agent of sudden death syndrome (SDS), and Heterodera glycines (causal agent of soybean cyst) (Koenning and Wrather 2010). The objectives of this research were to evaluate the effect of fall planted cover crops on soybean stands, the incidence and severity of soybean diseases, soilborne pathogen populations, soil microbial community structure in the bulk soil, and soybean yield within three separate cropping systems. The cropping systems were defined by how the fall planted cover crops were terminated in the spring (no-till, terminated with glyphosate; organic, terminated by incorporation; conventional tillage, terminated by glyphosate followed by incorporation). This research adds information about soil suppressiveness, which typically has been studied under "green manure" systems, with little to no research done in no-till systems.

\section{Materials and Methods}

Site description and experimental design. Field trials were conducted at four locations in east-central and western Illinois from 2010 to 2013 (2010-11, 2011-12, and 2012-13), with two sites located on university research farms (one conventional and one organic) and two on commercial farms using no-till cropping. The two university trials were conducted on the University of Illinois at Urbana-Champaign, Crop Sciences Research and Education Center (UIUC) (Champaign County in east-central Illinois), and Western Illinois University's Allison Organic Research and Demonstration Farm (WIU) (Warren County in western Illinois). The two on-farm trials were conducted on the Ayres Farm, near Bement (Piatt County in east-central Illinois), and the Hunt Farm, near Blandinsville (McDonough County in western Illinois).

The experiments were conducted using a randomized complete block design at each location. There were four replications per treatment in the UIUC, Ayres, and Hunt Farm field trials, and three replications in the WIU field trials. The cover crops used at the two university locations were canola, cereal rye, mustard, and rapeseed. At the two on-farm locations, only cereal rye and rapeseed were used. The planting rates for cover crops at all the locations were the same, $62.7 \mathrm{~kg} / \mathrm{ha}$ for cereal rye, $11.2 \mathrm{~kg} / \mathrm{ha}$ for canola, mustard, and rapeseed. Non-cover cropped (fallow) plots were used as control treatments at all locations. Experimental unit size, planting date for cover crops and soybean, planting rate of soybean, and soybean cultivars varied and were determined by practical considerations at each site. Information on the field trials and sequence of annual field management and data collection activities are listed in Table 1.

At the UIUC location, canola, cereal rye, mustard, rapeseed, and a fallow treatment were randomly assigned to each of the main plots planted in four blocks in the fall, and cover crops were incorporated into the soil with tillage after termination with glyphosate the following spring. Soybean seeds were planted 1 to 2 weeks after termination of cover crops, and at soybean planting, each cover crop main plot was divided into three subplots and inoculated with either $F$. virguliforme, $R$. solani, or left noninoculated as a control. To inoculate the plots with $F$. virguliforme or $R$. solani, soybean seeds were planted along with sorghum seed colonized by $F$. virguliforme (isolate Mont 1) or R. solani (isolate RS 1039) using the methods described by Huang and Hartman (1998).

At the WIU farm, there were six treatments (canola-incorporated, cereal rye-incorporated, cereal rye without tillage, mustard-incorporated, rapeseed-incorporated, and fallow) in each of three blocks in the first growing season (2010-11), and five treatments (canola, cereal rye, mustard, rapeseed, and fallow) in each of the three blocks in the second and third growing seasons (2011-12 and 2012-13). Except for the cereal rye no-till treatment in the first year, all cover crops were incorporated into the soil as green manure at WIU site, and soybean seeds were sown the following day or as soon as practical thereafter. The plots were not inoculated artificially with the expectation of natural infestation.

For the two on-farm locations (Ayres and Hunt), cereal rye, rapeseed, and fallow treatments were assigned randomly to each of the four blocks each fall, and the cover crops were terminated with glyphosate the following spring. Cover crops were not incorporated into the soil, and soybean seeds were planted directly into the terminated cover crops about 2 weeks later. Plots were not artificially inoculated with pathogens at either of the on-farm locations.

Cover crops were planted in $18.3 \mathrm{~m} \times 305 \mathrm{~m}$ randomized strip plots on the no-till farm sites, while the UIUC randomized plots were $3 \mathrm{~m} \times 30 \mathrm{~m}$, and depending on the year and field size, the WIU randomized plots were $3 \mathrm{~m}$ wide by 152 to $366 \mathrm{~m}$ in length.

Cover crops. Cereal rye (cv. Rymin), brown mustard (cv. Pacific Gold), winter canola (cv. Sumner), and rapeseed (cv. Dwarf Essex) were selected for evaluation in this study. Cover crops were established in the fall (late September/early October) each year following a short season corn hybrid. The following spring, cover crops were either terminated by using an herbicide (Ayres and Hunt, no-till farms), by incorporation (WIU, organic farm), or by an herbicide followed by incorporation (UIUC).

Soil collection. Soil samples were collected from the four locations in the spring each year at the time of soybean planting or shortly after (within 1 week), and before any inoculum was applied. Individual soil cores (15 to 20 ) were collected from each cover crop plot using a bulb planter (about $15 \mathrm{~cm}$ deep), following a random zigzag pattern in each cover crop plot. The soil samples were compared for soil suppressiveness, soilborne pathogen populations, and microbial community structure. Soils were sieved, and large pieces of plant residue and soil clods were removed. The soils were then mixed thoroughly in a plastic bag. After screening and mixing, a 50-ml subsample of each soil sample was stored at $-80^{\circ} \mathrm{C}$ prior to use for DNA extraction. Another 200-ml subsample was stored at $4^{\circ} \mathrm{C}$ and used

Table 1. Soil types, plot sizes, and the annual sequence of crop and field management used at four Illinois locations

\begin{tabular}{|c|c|c|c|c|c|c|c|c|c|c|c|}
\hline $\begin{array}{l}\text { Geographic } \\
\text { area }\end{array}$ & $\underset{\text { location }^{y}}{\text { Trial }}$ & Soil type & $\begin{array}{c}\text { Plot } \\
\operatorname{size}^{\mathrm{z}}(\mathrm{m})\end{array}$ & $\begin{array}{l}\text { Cover crop } \\
\text { planting date }\end{array}$ & $\begin{array}{l}\text { Cover crop } \\
\text { biomass } \\
\text { collection }\end{array}$ & $\begin{array}{c}\text { Tillage } \\
\text { date }\end{array}$ & $\begin{array}{c}\text { Soybean } \\
\text { planting date }\end{array}$ & $\begin{array}{l}\text { Soil sample } \\
\text { collection }\end{array}$ & $\begin{array}{l}\text { Soybean } \\
\text { stand count }\end{array}$ & $\begin{array}{l}\text { Foliar and root } \\
\text { disease rating }\end{array}$ & Harvest \\
\hline \multirow[t]{6}{*}{ Eastern IL } & \multirow[t]{3}{*}{ UIUC } & \multirow{3}{*}{$\begin{array}{l}\text { Drummer } \\
\text { Flanagan }\end{array}$} & \multirow[t]{3}{*}{$3 \times 30$} & 20 Sep 2010 & 5 May 2011 & Jun 2011 & 8 Jun 2011 & 22 Jun 2011 & 28 Jun 2011 & $22 \mathrm{Jul} 2011$ & Oct 2011 \\
\hline & & & & 3 Oct 2011 & 1 May 2012 & Jun 2012 & May 2012 & 27 May 2012 & 31 May 2012 & $17 \mathrm{Jul} 2012$ & Oct 2012 \\
\hline & & & & 15 Sep 2012 & 10 May 2013 & Jun 2013 & Jun 2013 & 25 Jun 2013 & 28 Jun 2013 & 2 Aug 2013 & Oct 2013 \\
\hline & \multirow[t]{3}{*}{ Ayres farm } & \multirow{3}{*}{$\begin{array}{l}\text { Drummer } \\
\text { Flanagan }\end{array}$} & \multirow{3}{*}{$18 \times 305$} & 20 Sep 2010 & 10 May 2011 & No tillage & 9 Jun 2011 & 25 Jun 2011 & 29 Jun 2011 & $21 \mathrm{Jul} 2011$ & Oct 2011 \\
\hline & & & & 5 Oct 2011 & 15 May 2012 & No tillage & May 2012 & 2 Jun 2012 & 8 Jun 2012 & $18 \mathrm{Jul} 2012$ & Oct 2012 \\
\hline & & & & 16 Sep 2012 & 17 May 2013 & No tillage & Jun 2013 & 21 Jun 2013 & 28 Jun 2013 & 3 Aug 2013 & Oct 2013 \\
\hline \multirow[t]{6}{*}{ Western IL } & \multirow[t]{3}{*}{ WIU } & \multirow[t]{3}{*}{ Sable } & \multirow[t]{3}{*}{$3 \times 152-366$} & Sep 2010 & Apr 2011 & 7 Jun 2011 & 8 Jun 2011 & 19 Jun 2011 & 7 Jul 2011 & 18 Aug 2011 & Oct 2011 \\
\hline & & & & Sep 2011 & Apr 2011 & Jun 2012 & 7 Jun 2012 & 18 Jun 2012 & 7 Jul 2012 & 9 Aug 2012 & Oct 2012 \\
\hline & & & & 3 Oct 2012 & Apr 2012 & Jun 2013 & 14 Jun 2013 & 25 Jun 2013 & 16 Jul 2013 & 8 Aug 2013 & Oct 2013 \\
\hline & \multirow[t]{3}{*}{ Hunt farm } & \multirow[t]{3}{*}{ Sable } & \multirow[t]{3}{*}{$18 \times 305$} & 8 Sep 2010 & Apr 2011 & No tillage & 19 May 2011 & 28 May 2011 & 1 Jun 2011 & 19 Aug 2011 & 20 Sep 2011 \\
\hline & & & & Sep 2011 & 21 Apr 2011 & No tillage & 10 May 2012 & 21 May 2012 & 30 May 2012 & 10 Aug 2012 & 14 Sep 2012 \\
\hline & & & & 3 Oct 2012 & 14 Apr 2012 & No tillage & 15 May 2013 & 25 May 2013 & 25 Jun 2013 & 9 Aug 2013 & 13 Sep 2013 \\
\hline
\end{tabular}

y UIUC: Field trial at University of Illinois at Urbana-Champaign; WIU: field trial at Western Illinois University Allison Organic Research and Demonstration Farm.

${ }^{\mathrm{z}}$ Plot size shown for UIUC field trial is the main plot size, and each main plot was divided into three subplots inoculated with different pathogens before soybean was planted. 
for SCN egg counts. The rest of the soil sample was stored at $4{ }^{\circ} \mathrm{C}$ until it was used in greenhouse bioassays to test for suppressiveness to $F$. virguliforme and $R$. solani.

Cover crop biomass measurement. Cover crop biomass was collected on each farm when cereal rye reached about $45 \mathrm{~cm}$ tall, just before termination. For the UIUC and Ayres farms, cover crop biomass was collected from three random $0.145 \mathrm{~m}^{2}$ quadrats in each cover crop plot. For the WIU and Hunt farms, cover crop biomass was collected from two random $0.145 \mathrm{~m}^{2}$ quadrats in each cover crop plot. Crop biomass weights were recorded after the samples were air-dried.

Soybean population counts. Soybean plant populations were counted on each farm approximately 2 weeks after planting. At the UIUC farm, soybean stands were counted in three random, $1-\mathrm{m}$ rows in each subplot (plot $=4$ soybean rows $\times 10 \mathrm{~m}$ ). At the Ayres farm, soybean stands were counted in three random 1-m rows in each cover crop plot. At the WIU (plot area $=4$ soybean rows $\times 152$ to $366 \mathrm{~m}$ ) and Hunt farms (plot area $=24$ soybean rows $\times 305 \mathrm{~m}$ ), soybean stand counts were determined in two random 5.33-m rows in each cover crop plot.

Field disease ratings. Incidence of foliar diseases (Septoria brown spot and bacterial blight) was evaluated separately at the R3 growth stage by counting the number of plants infested with a specific disease in the two inner rows in each experimental unit at UIUC. At the Ayres, Hunt, and WIU farms, whole plant incidence of foliar diseases was determined by counting the plants with symptoms from three random 1-m rows within each strip plot.

For a general root rot rating, root discoloration (possibly caused by one or more pathogens) was recorded. At the R4 to R6 growth stage, six to 10 randomly selected plants were carefully dug from the two inner rows at the UIUC and Ayres locations in each experimental unit. These roots were carefully washed to minimize damage to fine roots and visually rated for external discoloration using the scale described below. At the WIU and Hunt locations, six to 10 soybean roots were dug at the R4 to R6 growth stage from each experimental unit, and the roots were visually rated by destructively splitting roots in the field and evaluating for internal discoloration.

General root rot with root discoloration, was rated using a 1 to 5 scale according to the percentage of root discoloration; $1=$ roots with 0 to $20 \%$ discoloration; $2=21$ to $40 \%$ discoloration; $3=41$ to $60 \%$ discoloration; $4=61$ to $80 \%$; and $5=$ roots with 81 to $100 \%$ discoloration (Huang and Hartman 1998).

Lengths of eye-shaped lesions on these same roots were measured to rate Rhizoctonia root rot severity. Because few seedlings remained in most of the UIUC Rhizoctonia inoculated plots in 2011, soybean plants were saved for yield analysis only, and the roots were not collected from these plots for Rhizoctonia root rot severity ratings.

Greenhouse bioassay for soil suppressiveness. Inoculum of $F$. virguliforme was prepared following the modified methods of Melgar et al. (1994). F. virguliforme isolate Mont 1 was grown on potato dextrose agar (PDA) in 100-mm Petri dishes at $24^{\circ} \mathrm{C}$ for 3 weeks. Cornmeal and sand was mixed at $1: 4$ ratio and autoclaved at $121^{\circ} \mathrm{C}$ for an hour on two consecutive days. An entire Petri dish culture of a 3-week-old colony was cut into $0.8-\mathrm{cm}$ diameter pieces and transferred to the cornmeal/ sand mix. F. virguliforme was grown on the cornmeal/sand mix for 15 days, mixing daily after the third day of transfer.

$R$. solani isolate RS 1039 (anastomosis group AG 2B12) was cultured on PDA in 100-mm Petri dishes for 7 days, after which four plugs $(0.5 \mathrm{~cm}$ in diameter) were transferred into $50 \mathrm{ml}$ potato dextrose broth (PDB) in a $125 \mathrm{ml}$ flask and grown for another week on an orbital shaker $(1 \times 100 \mathrm{RPM})$ at $24^{\circ} \mathrm{C}$. The broth was removed from the mycelium using a Buchner vacuum funnel, and the mycelium was resuspended in $100 \mathrm{ml}$ of distilled water and minced using a blender for $30 \mathrm{~s}$. The mycelial fragments were then mixed with clean fine sand at a ratio of $50 \mathrm{ml}$ sand $(80 \mathrm{~g}) / 0.1 \mathrm{~g}$ mycelia $(\mathrm{Li}$ et al. 2008; Liu and Sinclair 1991).

Greenhouse bioassays were conducted using a randomized complete block design. Bulk soil samples, approximately 10 liters per plot, were collected from each location at the time of soybean planting. Subsamples of these soil samples were infested with $F$. virguliforme ( $500 \mathrm{ml}$ field soils mixed with $10 \mathrm{ml} F$. virguliforme colonized cornmeal in a 50:1 ratio), $R$. solani $(500 \mathrm{ml}$ soil from each experimental unit was mixed with $25 \mathrm{ml} R$. solani-infested sand), or clean sand, and the infested/noninfested soils were evenly distributed into five Cone-tainers (Ray Leach SC-10 Super Cell, diameter: $4 \mathrm{~cm}$, height: $21 \mathrm{~cm}$ ). One soybean seed (cultivar Pana, a Rhizoctonia root rot and SDS susceptible cultivar) was planted in each Cone-tainer (five Cone-tainers received the same treatment as one experimental unit). The block number from the field plot design was kept the same for the block designations used for the greenhouse studies. Plants were maintained in the greenhouse for 4 weeks at $24^{\circ} \mathrm{C}$ with a $16 \mathrm{~h}$ photoperiod before diseases were evaluated. Supplemental light was provided by 1,000 watt high pressure, sodium vapor lights $\left(156 \mu \mathrm{E} \mathrm{s}^{-1} \mathrm{~m}^{-2}\right)$.

The roots were harvested and rated for Rhizoctonia root rot and SDS as previously described (Marzano et al. 2015). One month after planting, the Cone-tainers were cut, plants were removed, and roots were washed. For Rhizoctonia root rot, the rating was based on length of lesions caused by $R$. solani, measured in millimeters on roots of the plants grown in $R$. solani-infested soil. SDS severity was rated using the same 1 to 5 scale for general root rot rating (Huang and Hartman 1998) based on the percentage of discoloration on the stem and roots.

SCN egg counts. Cysts of SCN were extracted following a previous reported method with modifications (Niblack et al. 1993). Field soil samples collected from the cover crop plots, described above, were broken up by hand, and then the crumbled soil was gradually added to $500 \mathrm{ml}$ water until a final volume of $600 \mathrm{ml}$ was reached. The soil suspension was mixed well, and the supernatant was poured onto nested 20 mesh $(850 \mu \mathrm{m})$ and 60 mesh $(250 \mu \mathrm{m})$ sieves before the soil settled. This process was repeated three times. The residue collected on the 60mesh sieve was ground with a rubber stopper, and the eggs were collected on nested 100 mesh $(150 \mu \mathrm{m})$ and 500 mesh $(25 \mu \mathrm{m})$ sieves. The eggs were washed into a beaker with $50 \mathrm{ml}$ of water and stained with $1 \mathrm{ml}$ egg staining solution $(0.35 \mathrm{~g}$ of acid fuchsin, $250 \mathrm{ml}$ lactic acid, $750 \mathrm{ml}$ water). Nematode eggs were counted using a dissecting microscope with $10 \times$ magnification.

Quantification of soybean pathogens using qPCR. Total DNA was extracted from the field soil samples collected from each cover crop plot using the FastDNA SPIN Kit for Soil (MP Biomedicals, Solon, $\mathrm{OH}$ ), followed by purification with the E.Z.N.A. Micro Elute DNA cleanup kit (Omega Bio-tek Inc., Norcross, GA). The six pathogens quantified were Colletotrichum spp. (soybean anthracnose) (Haudenshield et al. 2012), F. virguliforme (Li et al. 2008), H. glycines (soybean cyst) (Lambert et al. 2005), Macrophomina phaseolina (charcoal rot) (Haudenshield et al. 2012), Cadophora gregata (brown stem rot) (Malvick and Impullitti 2007), and Phytophthora sojae (Phytophthora root and stem rot) (Haudenshield et al. 2017). The genomic DNA of the six pathogens was quantified with multiplex qPCR, which combines several PCR assays together into one reaction. The DNA of several pathogens was amplified simultaneously but detected independently using reporters with distinct spectra. C. truncatum, M. phaseolina, and $P$. gregata were quantified in one QPCR reaction, while $F$. virguliforme and $H$. glycines were quantified in another reaction. $P$. sojae was quantified alone. All the $\mathrm{qPCR}$ assays were performed in a Stratagene MX3005P real-time thermal cycler with a total reaction volume of $25 \mu \mathrm{l}$ containing $5 \mu \mathrm{l}$ of test DNA. The thermal profile was as follows: $2 \mathrm{~min}$ at $60^{\circ} \mathrm{C}, 2 \mathrm{~min}$ at $95^{\circ} \mathrm{C}$, and 40 cycles of $15 \mathrm{~s}$ at $95^{\circ} \mathrm{C}$ and $30 \mathrm{~s}$ at $60^{\circ} \mathrm{C}$. Primers and probes used for each pathogen are listed in Table 2.

Soil bacterial and fungal microbial community structure analysis. An automated ribosomal intergenic spacer analysis (ARISA) was used for rapid estimation of the effect of different cover crops on soil microbial community composition. ARISA is a culture-independent DNA profiling approach for comparing the effect of different treatments on microbial community composition and structure (Anderson and Cairney 2004; Bastian et al. 2009; Danovaro et al. 2006). ARISA has been demonstrated to be comparable with high-throughput sequencing methods in revealing patterns in beta diversity, and has the advantages of being relatively inexpensive with high throughput, providing high statistical power to detect changes in microbial community structure (Jami et al. 2014; Spencer et al. 2011). The region of the rRNA gene between the 
small and large subunits is called the intergenic spacer region (ISR), and the ISR of different microbial species differ both in length and nucleotide sequence. Total DNA was extracted and purified as described previously. PCR for ARISA was performed following a modified method of Fisher and Triplett (1999). PCR reactions contained 0.5 OminiMix HS (Takara Bio Inc., Otsu, Shiga, Japan) bead (1.5 U Taq polymerase, $200 \mu \mathrm{M}$ dNTP, $4 \mathrm{mM} \mathrm{Mgcl}$, and $25 \mathrm{mM}$ HEPES buffer), 10 pmol of each primer, and about $10 \mathrm{ng}$ soil DNA in a final volume of $25 \mu \mathrm{l}$. The primers used for bacterial ARISA were 1406f (universal 16S rRNA gene: 5'-TGYACACACCGCCCGT-3') labeled with 6-fluorescein amidite (FAM) and $23 \mathrm{Sr}$ (bacteria-specific, $23 \mathrm{~S}$ rRNA gene: 5'-GGG TTBCCCCATTCRG-3') (Fisher and Triplett 1999). All PCR was carried out in a PTC-100 Programmable Thermal Controller (MJ Research, Inc., Watertown, MA). The initial denaturation was performed at $94^{\circ} \mathrm{C}$ for $2 \mathrm{~min}$, followed by 30 cycles of $94^{\circ} \mathrm{C}$ for $35 \mathrm{~s}, 55^{\circ} \mathrm{C}$ for $45 \mathrm{~s}$, and $72^{\circ} \mathrm{C}$ for $2 \mathrm{~min}$, with a final extension carried out at $72^{\circ} \mathrm{C}$ for $2 \mathrm{~min}$. The fungal intergenic spacer region containing the two internal transcribed spacers (ITS) and the 5.8S rRNA gene (ITS1-5.8S-ITS2) was amplified using primer set ITS1-F (5'-CTTGGTCATTTAGAGGAAG TAA- $3^{\prime}$ ), and ITS4 (5'-TCCTCCGCTTATTGATATGC-3') (Kennedy et al. 2006). The forward primer ITS1-F was labeled with 6-FAM. The initial denaturation was performed at $95^{\circ} \mathrm{C}$ for $4 \mathrm{~min}$, followed by 35 cycles of $95^{\circ} \mathrm{C}$ for $1 \mathrm{~min}, 53^{\circ} \mathrm{C}$ for $30 \mathrm{~s}, 72^{\circ} \mathrm{C}$ for $1 \mathrm{~min}$, with a final extension carried out at $72^{\circ} \mathrm{C}$ for $7 \mathrm{~min}$.

ARISA-PCR products were sent to the Keck Center for Functional Genomics at the University of Illinois (Urbana, IL) for denaturing capillary electrophoresis using an ABI 3730xl Genetic Analyzer (PE Biosystems, Foster City, CA). Electrophoresis conditions were $63^{\circ} \mathrm{C}$ and $15 \mathrm{kV}$ with a run time of $120 \mathrm{~min}$ using the POP-7 polymer. A custom 50 to 1,000 bp Rhodamine X-labeled size standard (Bioventures, Murfreesboro, TN) was used as the size marker standard for each sample.

Soybean yield. Depending on the site, research or on-farm plots were harvested using either a research or traditional combine. Soybean seed weight was standardized to $13 \%$ moisture. UIUC and WIU plots were 4-row plots with center two harvested. Ayres and Hunt farms were $18.3 \mathrm{~m}$ wide ( 24 rows) strips harvested for $305 \mathrm{~m}$. Yield was determined with a yield monitor.

Data analysis. Analysis of variance (ANOVA) was performed on cover crop biomass weights, soybean population counts, field foliar disease incidence, Rhizoctonia root rot lesion length in the field and greenhouse, nematode egg counts, soybean yield, and six soilborne pathogen quantification values from QPCR using PROC MIXED in SAS version
9.3 (SAS Institute Inc., Cary, NC). For each model, cover crop was designated as the fixed effect, and block and associated interactions were designated as random effects. Experimental designs were different among locations and different years; therefore, ANOVA was performed separately from location to location and year to year. Count data (stand count, foliar disease incidence data, and nematode egg counts) were log or square root transformed to meet normality and constant variance assumptions. For ordinal scale data (general root rot rating in the field and greenhouse), generalized linear mixed models were fitted using PROC GLIMMIX in SAS specifying the appropriate distributions of the response (binomial, negative binomial, or Poisson). Tukey-Kramer-type multiple comparison was done using the "lsmeans" statement and specifying "adj=Tukey" when comparing the differences of LS-means.

For ARISA data analysis, size calling and profile alignment were carried out using GeneMarker V 1.85 software (SoftGenetics LLC, State College, PA). A fluorescence threshold of 100 fluorescence units was used to include the maximum number of peaks while excluding background fluorescence. A bin table containing different sized peaks and their areas were exported from GeneMarker. ANOVA was performed to analyze the effect of cover crops on the number of operational taxonomic units (OTU) in the soil with SAS. Analysis of similarities (ANOSIM) and nonmetric multidimensional scaling (NMDS) were performed with Primer 6 (Plymouth Marine Laboratory, Primer-E) by importing the bin table profile into Primer 6. Before ANOSIM and NMDS, the fluorescent signal of each intergenic spacer peak was normalized to account for run-to-run variations in signal detection by dividing the area of an individual peak by the total area of peaks detected in each profile. Each peak represents a proportion of the total fluorescence for each sample (Kent et al. 2007; Yannarell and Triplett 2005).

\section{Results}

Cover crop biomass measurement. A significant difference in biomass was observed among different cover crops at three field locations in different years (Fig. 1). Cereal rye performed better in both winter hardiness and biomass production than the Brassica cover crops over all four farms in three years. Mustard did not overwinter on the UIUC or WIU farms in 2011 and 2013. Rapeseed did not overwinter on the Ayres and Hunt farms in 2012 and 2013. In 2011, cereal rye produced more $(P<0.05)$ biomass than the other cover crops on three farms (UIUC, Ayres, and WIU). In 2012, cereal rye, rapeseed, and canola produced more $(P<0.05)$ biomass than mustard on the UIUC farm (Fig. 1). In 2013, cereal rye produced more $(P<0.05)$ biomass than other cover crops on the UIUC farm.

Table 2. Primers and probes used for the quantification of populations of six pathogens in the qPCR procedure

\begin{tabular}{|c|c|c|c|}
\hline Pathogen & Disease & Primer and probe ${ }^{\mathrm{z}}$ & Sequences \\
\hline \multirow[t]{3}{*}{ Colletotrichum truncatum } & Anthracnose & ColSoy1 forward primer & 5'-GCGTCTTTCAACCCTCAAG-3' \\
\hline & & ColSoy1 reverse primer & 5'-GTTACTACGCAAAGGAGGCT-3' \\
\hline & & Colsoy1-Probe & 5'-HEX-AAAGGTAGTGGCGGACCCTC-IBFQ-3' \\
\hline \multirow[t]{3}{*}{ Macrophomina phaseolina } & Charcoal rot & Macrp-F1 forward primer & $5^{\prime}$-CGAAGCGAGATCCTCAGTCC-3' \\
\hline & & Macrp-R1 reverse primer & 5'-CGGTGTACTCTTCTGCGGC-3' \\
\hline & & Macrp-P1 Probe & 5'-TEX615-AAAGGTAGTGGCGGACCCTC-IBFQ-3' \\
\hline \multirow[t]{3}{*}{ Cadophora gregata } & Brown stem rot & BSRqPCRf1 forward primer & 5'-CAAACCAGGGCCGATCAG-3' \\
\hline & & BSRqPCRr1 reverse primer & 5'-CGGATTCAGCGTAAAAAATGG-3' \\
\hline & & BSRqPCRpb1probe & 5'-6FAM-CTCCCGTATGGTTTCT-MGBNFQ-3' \\
\hline \multirow[t]{3}{*}{ Fusarium virguliforme } & Sudden death & Fv-li-F Forward primer & 5'-GGCTGAACTGGCAACTTGGA-3' \\
\hline & syndrome & Fv-li-R reverse primer & 5'-CAAAGCTTCATTCAATCCTAATACAATC-3' \\
\hline & & Fv-Li-Pb Probe & 5'-VIC-TCTTCTAGGATGGGCTGGT/MGBNFQ/-3' \\
\hline \multirow[t]{4}{*}{ Heterodera glycines } & Soybean cyst & $\mathrm{HgCM} 1 \mathrm{TM}$ forward primer & $5^{\prime}$-CCAAGGACGTGGTCAATTACA-3' \\
\hline & & HgCM1TM reverse primer & $5^{\prime}$-CCCTGCGCCGAAACACT-3' \\
\hline & & Hg-cmla-Fam probe & 5'-6FAM-TTCATAACAACATCTCAATCG-MGBNFQ-3' \\
\hline & & Hg-cmlb-Fam probe & 5'-6FAM-TTCATCAAAACATCTCAATCG-MGBNFQ-3' \\
\hline \multirow[t]{3}{*}{ Phytophthora sojae } & Phytophthora & PS12F forward primer & 5'-CAGGTTTCAGCGATCTCCATCCAAGTG-3' \\
\hline & root and stem rot & PS6R reverse primer & 5'-CACATTGCGGAAAAGGAGGTGATTGCT-3' \\
\hline & & PSO-P5 probe & 5'-TEX615-TGCCGACGTCGAGGTCAGCAACCATTCAA-IBRQ-3' \\
\hline
\end{tabular}

${ }^{\mathrm{z}}$ The primers for detecting $C$. truncatum are universal for Colletotrichum spp. The primers and probe for $F$. virguliforme amplification were designed for analysis of small-subunit mitochondrial rRNA genes of $F$. virguliforme isolates. The $P$. sojae primers and probe for this fluorogenic, $5^{\prime}$-exonuclease assay target the DNA sequences of a gypsy-like transposable retroelement. Primers and probes for the other four pathogens were designed based on the ITS region. 
Soybean population evaluations in the field. Soybean plant populations were not significantly different among cover crop treatments on the Ayres and Hunt Farms in all three years, where the plots were not artificially inoculated with pathogens (Table 3). Soybean populations were not significantly different among cover crop treatments on the WIU farm in 2011 and 2012; the only significant result caused by cover crop treatment was detected in 2013, where the rapeseed and cereal rye plots had significantly higher $(P=0.0049)$ soybean population counts than those observed in the mustard treatment plots (Table 3).

Under high disease pressure, cereal rye and rapeseed significantly maintained soybean stands when Rhizoctonia root rot was severe. At UIUC, the interaction of cover crop and pathogen inoculation was significant, and soybean plant populations were significantly different among cover crop treatments within $R$. solani inoculated plots $(P<0.0001)$. Compared with the noninoculated plots, $R$. solani infestation caused reductions in the number of soybean plants in the fallow, mustard, and canola plots, but not in the cereal rye plots
(Supplementary Fig. S1). The cereal rye plots had similar plant counts to the rapeseed plots, but the number of soybean plants in the cereal rye plots were significantly higher than that those in the canola, mustard, and fallow plots (Table 3). In 2012, pathogen inoculation caused significant difference in soybean stand counts $(P=$ $0.0011)$, and both $F$. virguliforme (20 plants $/ \mathrm{m})$ and $R$. solani $(20$ plants $/ \mathrm{m}$ ) inoculated plots had significantly lower soybean stand counts than the noninoculated plots (26 plants $/ \mathrm{m})$. However, there were no significant differences among cover crop treatments within these plots (Table 3). In 2013, stand counts were significantly different among cover crop plots $(P=0.0072)$ on the UIUC farm. Soybean stand counts were highest in the cereal rye plots ( 25 plants $/ \mathrm{m})$, and these plant numbers were significantly higher than that in the fallow treatment plots (18 plants $/ \mathrm{m})$.

Naturally occurring field foliar disease ratings. Overall, foliar disease levels were low in the four field trials throughout the three years of the study. The incidence levels of brown spot (caused by Septoria glycines) and bacteria blight (caused by Pseudomonas

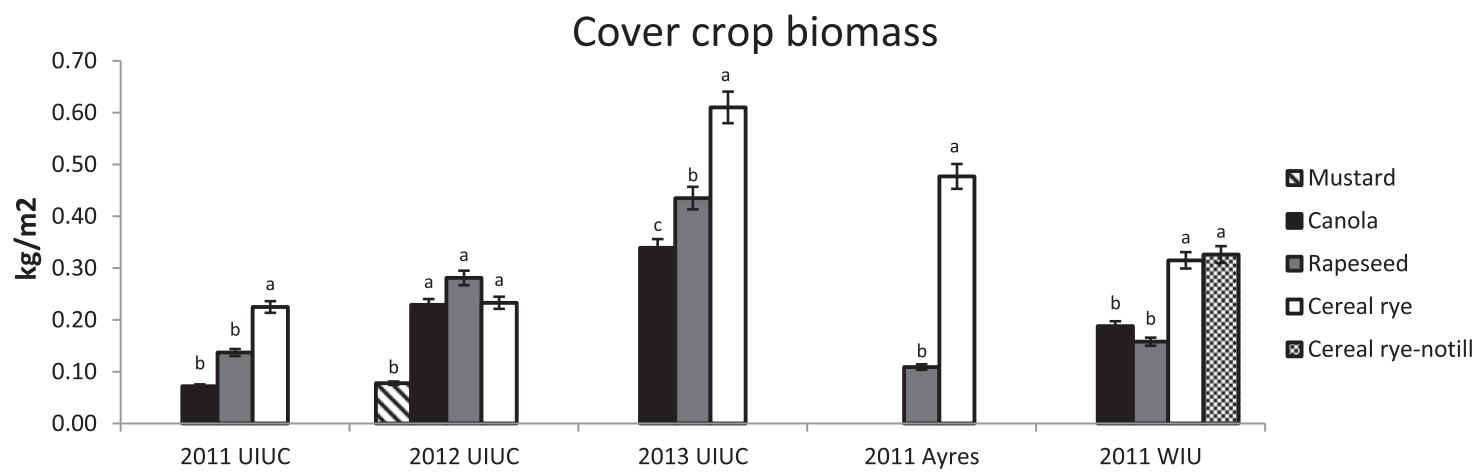

Fig. 1. Biomass production levels of different cover crops at University of Illinois, Urbana-Champaign (UIUC), Ayres, and Western Illinois University (WIU) farms from 2011 to 2013. Mustard did not overwinter at the UIUC location in 2011 and 2013, so mustard biomass data were not collected. Biomass of different cover crops were not significantly different if followed by the same letter according to the multiple comparison test with Tukey's adjustment method at $\alpha=0.05$. On the Ayres farm in 2012 and 2013 , only rye biomass was collected in those two years; therefore, analysis of variance was not conducted in 2012 and 2013 . Biomass of different cover crops were not significantly different if followed by the same letter according to the multiple comparison test with Tukey's adjustment method at $\alpha=0.05$. On the WIU farm in 2011, rapeseed did not overwinter, so only the biomass of cereal rye, cereal rye-notill, mustard, and canola were compared. Biomass of different cover crops were not significantly different if followed by the same letter according to the multiple comparison test with Tukey's adjustment method at $\alpha=0.05$.

Table 3. Soybean stand counts in cover crop treatment plots at four Illinois locations from 2011 to 2013

\begin{tabular}{|c|c|c|c|c|c|c|c|}
\hline \multirow[b]{3}{*}{ Year } & \multirow[b]{3}{*}{ Cover crop } & \multicolumn{6}{|c|}{ Soybean plant counts (plants/m) } \\
\hline & & \multicolumn{3}{|c|}{ UIUC $^{\mathbf{z}}$} & \multirow[b]{2}{*}{ Ayres } & \multirow[b]{2}{*}{ WIU } & \multirow[b]{2}{*}{ Hunt } \\
\hline & & RS-inoculated & FV-inoculated & $\overline{\text { Noninoculated }}$ & & & \\
\hline \multirow[t]{6}{*}{2011} & Canola & $9.2 \mathrm{bc}$ & 25.3 & 26.1 & ND & 19.0 & $\overline{\mathrm{ND}}$ \\
\hline & Fallow & $5.5 \mathrm{c}$ & 26.1 & 28.0 & 18.1 & 19.5 & 22.5 \\
\hline & Mustard & $5.6 \mathrm{c}$ & 24.0 & 24.2 & ND & 18.7 & ND \\
\hline & Rapeseed & $16.6 \mathrm{ab}$ & 26.0 & 26.5 & 21.0 & 18.0 & 20.7 \\
\hline & Cereal rye & $24.8 \mathrm{a}$ & 25.5 & 27.8 & 20.7 & 17.9 & 21.9 \\
\hline & Cereal rye-no till & ND & ND & ND & ND & 15.6 & ND \\
\hline \multirow[t]{5}{*}{2012} & Canola & 24.2 & 24.2 & 24.2 & ND & 19.8 & ND \\
\hline & Fallow & 24.3 & 24.3 & 24.3 & 11.5 & 25.7 & 22.5 \\
\hline & Mustard & 22.1 & 22.1 & 22.1 & ND & 24.1 & ND \\
\hline & Rapeseed & 22.2 & 22.2 & 22.2 & 12.2 & 21.6 & 20.7 \\
\hline & Cereal rye & 22.8 & 22.8 & 22.8 & 10.8 & 21.4 & 21.9 \\
\hline \multirow[t]{5}{*}{2013} & Canola & $21.7 \mathrm{ab}$ & 20.1 & 24.2 & ND & $15.0 \mathrm{ab}$ & ND \\
\hline & Fallow & $20.5 \mathrm{~b}$ & 18.4 & 23.4 & 14.9 & $14.9 \mathrm{ab}$ & 23.9 \\
\hline & Mustard & $21.4 \mathrm{ab}$ & 20.4 & 23.6 & ND & $12.0 \mathrm{~b}$ & ND \\
\hline & Rapeseed & $21.0 \mathrm{ab}$ & 18.8 & 24.0 & ND & $18.5 \mathrm{a}$ & 23.0 \\
\hline & Cereal rye & $22.5 \mathrm{a}$ & 20.7 & 24.2 & 15.4 & $17.7 \mathrm{a}$ & 23.4 \\
\hline
\end{tabular}

y WIU: Field trial at Western Illinois University Allison Organic Research and Demonstration farm; soybean stand count values within a location and year followed by the same letter were not significantly different based on multiple comparison test with Tukey's adjustment method at $\alpha=0.05$. ND: no data were collected.

${ }^{\mathrm{z}}$ UIUC: Field trial at the University of Illinois, Urbana-Champaign. In 2011 and 2013, the interaction between cover crop and pathogen inoculation was significant for the UIUC field trial, and a cover crop effect was significantly different within Rhizoctonia solani inoculated plots. Therefore, data shown are soybean stand counts in plots with different previous cover crops that were artificially inoculated with $R$. solani. Data from 2012 were averaged over pathogen inoculation treatments since the interaction between cover crop and pathogen inoculation was not significant. RS-inoculated means $R$. solani inoculated subplots, and FVinoculated means Fusarium virguliforme inoculated subplots. 
syringae pv. glycinea) were zero in most of the cover crop plots, and there were no significant differences in foliar disease incidence levels among the cover crop treatments at the UIUC, WIU, and Hunt trials in any year (insignificant data not shown). However, significant differences $(P=0.0114)$ in brown spot incidence levels were observed at the Ayres Farm trial in 2012 where the incidence of brown spot was significantly lower in the cereal rye treatment plots $(0.2$ infected plants $/ \mathrm{m}$ ) than in the fallow plots (3.9 infected plants $/ \mathrm{m}$ ).

Root diseases rating. Root disease severity was very low on soybean plants grown in the noninoculated fields, and no significant differences in general root rot (at Ayres, severity ratings ranged from 0.03 to 0.18 ; at Hunt, from 0.4 to 0.9 ; and at WIU from 0.4 to 1.2), or Rhizoctonia root rot severity (at Ayres, lesion lengths ranged from 0.2 to $1.0 \mathrm{~cm}$; at Hunt, from 0.2 to $0.9 \mathrm{~cm}$; and at WIU, from 0.2 to $0.9 \mathrm{~cm}$ ) were observed over the three years of the study.

However, in the $F$. virguliforme and $R$. solani inoculated UIUC field trials, Rhizoctonia root rot severity was significantly lower in certain cover crop plots in 2011 and 2013, and significant reductions in SDS severity were also observed in 2011 and 2013. In 2011, $R$. solani caused tremendous damage to soybean plants in the inoculated UIUC field trial, and most seedlings were killed in the plots previously planted to canola, mustard, and the fallow plots. However, soybean seedlings were not affected by $R$. solani in plots previously planted to rye. In 2013, Rhizoctonia root rot severity and general root rot severity were significantly lower in plots previously planted to rye, when compared with severity levels on plants grown in the fallow plots in the UIUC field trial $(P<0.05$, Table 4$)$.

Greenhouse bioassay for soil suppressiveness to $F$. virguliforme and $R$. solani. No significant differences in soil suppressiveness to $F$. virguliforme associated with cover crop treatments were detected in soils collected from the UIUC, Ayres, and Hunt farms in any of the three years. The only difference among cover crop treatments on suppressiveness to $F$. virguliforme was observed with soils collected from the UIUC location in $2013(P=0.041)$. In this instance, SDS severity was significantly lower on soybeans planted into soil

Table 4. Rhizoctonia root rot severity and general root rot severity ratings on soybean root systems collected from cover crop treatment plots in the University of Illinois, Urbana-Champaign (UIUC) field trails over three years

\begin{tabular}{llllc}
\hline Location & Year & Cover crop & $\begin{array}{c}\text { Rhizoctonia } \\
\text { root rot }(\mathbf{c m})^{\mathbf{y}}\end{array}$ & $\begin{array}{c}\text { General } \\
\text { root rot }^{\mathbf{2}}\end{array}$ \\
\hline UIUC & 2011 & Canola & Extremely severe & 1.6 \\
& Fallow & Extremely severe & 1.2 \\
& Mustard & Extremely severe & 1.8 \\
& & Rapeseed & Severe & 1.2 \\
& & Cereal rye & Trace & 1.3 \\
& \multirow{2}{*}{2012} & Canola & 1.4 & 1.0 \\
& & Fallow & 1.0 & 1.8 \\
& Mustard & 0.7 & 1.3 \\
& Rapeseed & 1.5 & 1.5 \\
& Cereal rye & 1.1 & 1.1 \\
& \multirow{2}{*}{2013} & Canola & $2.2 \mathrm{ab}$ & $2.8 \mathrm{a}$ \\
& Fallow & $2.9 \mathrm{~b}$ & $3.3 \mathrm{a}$ \\
& Mustard & $1.8 \mathrm{ab}$ & $2.5 \mathrm{a}$ \\
& Rapeseed & $1.9 \mathrm{ab}$ & $2.5 \mathrm{a}$ \\
& Cereal rye & $1.5 \mathrm{a}$ & $1.6 \mathrm{~b}$ \\
\hline
\end{tabular}

y Rhizoctonia root rot severity was compared on soybean root systems grown in Rhizoctonia solani inoculated cover crop plots. Severity of Rhizoctonia root rot was not significantly different if followed by the same letter according to the LSD test at $\alpha=0.05$. Roots were not collected from UIUC field plots in 2011, because the pathogen killed most of the soybean seedlings in most plots, and any existing seedlings were saved for yield analysis.

${ }^{\mathrm{z}}$ General root rot severity was compared on soybean root systems grown in Fusarium virguliforme inoculated cover crop plots. Severities of general root rot were not significantly different if followed by the same letter according to the multiple comparison test with Tukey's adjustment method at $\alpha=$ 0.05 . The general root rot severity was rated using a 1 to 5 scale, where $1=$ roots with 0 to $20 \%$ discoloration, $2=21$ to $40 \%$ discoloration, $3=41$ to $60 \%$ discoloration, $4=61$ to $80 \%$ discoloration, and $5=$ roots with 81 to $100 \%$ discoloration. collected from the rye plots (SDS disease severity score $=2$ ) when compared with the fallow and canola plots (SDS disease severity score $=4)$. No differences in soil suppressiveness to $F$. virguliforme were observed with soil collected from the WIU farm in any year.

The effect of cover crops on improving soil suppressiveness to $R$. solani also varied over locations and years (Table 5). In 2011, significant differences in soil suppressiveness to $R$. solani were observed in soils collected from three of the field locations, including UIUC, Ayres, and Hunt farms $(P<0.05)$. For the bioassay using soil from the 2011 UIUC field location, Rhizoctonia root rot severity was significantly lower on soybeans planted in soil collected from the cereal rye and rapeseed plots than it was in soil from the canola and fallow plots (Table 5). For the bioassay using soil from the 2011 Ayres and Hunt field locations, Rhizoctonia root rot severity was significantly lower on plants grown in soil collected from rapeseed plots than it was in soil from the fallow plots (Table 5). In 2012, bioassays with soils collected from UIUC, Ayres, and WIU field trials had similar results, in that soybeans planted in soils collected from cereal rye and rapeseed plots had significantly lower levels of Rhizoctonia root rot than soybeans planted in soil collected from the other treatment plots (Table 5). In 2013, significant differences in soil suppressiveness were detected in soil collected from the UIUC and Hunt field trials, and cereal rye and rapeseed treated soils had the highest level of soil suppressiveness to $R$. solani when compared with that seen in the soils from the other treatments from both of these locations (Table 5).

Soybean cyst nematode counts. SCN egg counts per $100 \mathrm{ml}$ soil were compared over cover crops treatments at the four trial locations. Significant differences in SCN egg counts were detected at multiple locations every year $(P<0.05)$. Rapeseed, cereal rye, and canola showed different levels of effectiveness for reducing egg counts, and rapeseed showed the most consistent and significant ability to suppress nematodes. SCN egg counts were significantly different among cover crop treatment soils collected from the UIUC, Ayres, and WIU field trials in 2011, from the WIU and Hunt field trials in 2012, and from the Ayres and WIU field trials in 2013 (Table 6).

Table 5. Lesion length on soybean roots inoculated with Rhizoctonia solani in greenhouse bioassays to evaluate the suppressive effect of different cover crops to $R$. solani with soil collected from four Illinois locations from 2011 to 2013

\begin{tabular}{|c|c|c|c|c|}
\hline \multirow[b]{2}{*}{ Location } & \multirow[b]{2}{*}{ Cover crop } & \multicolumn{3}{|c|}{$\begin{array}{l}\text { Lesion length on soybean roots } \\
\text { caused by } R \text {. solani }(\mathrm{cm})^{\mathrm{w}}\end{array}$} \\
\hline & & 2011 & 2012 & 2013 \\
\hline \multirow[t]{5}{*}{ UIUC $^{\mathrm{x}}$} & Canola & $3.2 \mathrm{~b}$ & $1.9 \mathrm{bc}$ & $1.3 \mathrm{ab}$ \\
\hline & Fallow & $3.7 \mathrm{~b}$ & $2.1 \mathrm{c}$ & $2.5 \mathrm{ab}$ \\
\hline & Mustard & $2.1 \mathrm{ab}$ & $2 c$ & $2.7 \mathrm{~b}$ \\
\hline & Rapeseed & $2.9 \mathrm{ab}$ & $1.3 \mathrm{ab}$ & $0.9 \mathrm{a}$ \\
\hline & Cereal rye & $1.3 \mathrm{a}$ & $0.9 \mathrm{a}$ & $1.1 \mathrm{a}$ \\
\hline \multirow[t]{3}{*}{ Ayres $^{\mathrm{y}}$} & Fallow & $2.8 \mathrm{~b}$ & $1.5 \mathrm{~b}$ & 0.6 \\
\hline & Rapeseed & $1.6 \mathrm{a}$ & ND & ND \\
\hline & Cereal rye & $2.5 \mathrm{~b}$ & $0.8 \mathrm{a}$ & 0.6 \\
\hline \multirow[t]{6}{*}{ WIUz } & Canola & 2.1 & $1.9 \mathrm{ab}$ & 1.1 \\
\hline & Fallow & 2.9 & $2.5 \mathrm{~b}$ & 1.4 \\
\hline & Mustard & 2.2 & $2.1 \mathrm{ab}$ & 1.1 \\
\hline & Rapeseed & 2.5 & $1.6 \mathrm{ab}$ & 1.0 \\
\hline & Cereal rye & 1.9 & $0.9 \mathrm{a}$ & 0.8 \\
\hline & Cereal rye no-till & 2.4 & ND & ND \\
\hline \multirow[t]{3}{*}{ Hunt } & Fallow & $2.4 \mathrm{~b}$ & 1.7 & $2.1 \mathrm{~b}$ \\
\hline & Rapeseed & $1.0 \mathrm{a}$ & 2.0 & $1.5 \mathrm{a}$ \\
\hline & Cereal rye & $1.4 \mathrm{ab}$ & 1.5 & $1.1 \mathrm{a}$ \\
\hline
\end{tabular}

${ }^{\mathrm{w}}$ Means followed by the same letter are not significantly different based on the multiple comparison test with Tukey's adjustment method at $\alpha=$ 0.05. ND: no data were collected.

x Field trial at University of Illinois, Urbana-Champaign.

y Rapeseed did not overwinter in the Ayres field trials in 2012 and 2013, so soil was not collected from the rapeseed plots in those years.

${ }^{\mathrm{z}}$ Field trial at Western Illinois University Allison Organic Research and Demonstration Farm. In 2012 and 2013, the cereal rye-no till treatment was not planted at the WIU location. 
For soil collected in 2011 from the UIUC location, the lowest egg counts were detected in soil from the canola plots ( $85 \mathrm{eggs})$, followed by the cereal rye (149 eggs) and rapeseed (231 eggs) plots. The egg counts in soils from the canola plots were also significantly lower than those in soil from the fallow plots (461 eggs) and mustard plots (305 eggs). No significant differences in SCN egg counts were observed among treatments in the soils collected in 2012, from the UIUC location. Results from the Ayres farm in 2011, showed there were significantly fewer SCN eggs in soil from the rapeseed (219 eggs) plots and the cereal rye plots (288 eggs) than in soil from the

Table 6. Soybean cyst nematode (SCN) egg counts in soil collected from cover crop treatment plots at four Illinois locations from 2011 to 2013

\begin{tabular}{llccc}
\hline & & \multicolumn{3}{c}{ SCN egg count (eggs/100 $\mathbf{~ m l ~ s o i l ) ~}$} \\
\cline { 3 - 5 } Location & Cover crop & $\mathbf{2 0 1 1}$ & $\mathbf{2 0 1 2}$ & $\mathbf{2 0 1 3}$ \\
\hline UIUC $^{\mathbf{x}}$ & Canola & $85 \mathrm{a}$ & 111 & 85 \\
& Fallow & $461 \mathrm{~b}$ & 153 & 80 \\
& Mustard & $305 \mathrm{~b}$ & 155 & 74 \\
& Rapeseed & $231 \mathrm{ab}$ & 125 & 67 \\
& Cereal rye & $149 \mathrm{ab}$ & 101 & 48 \\
Ayres $^{\mathrm{y}}$ & Fallow & $885 \mathrm{~b}$ & 105 & $222 \mathrm{~b}$ \\
& Rapeseed & $219 \mathrm{a}$ & $\mathrm{ND}$ & $\mathrm{ND}$ \\
& Cereal rye & $288 \mathrm{ab}$ & 121 & $63 \mathrm{a}$ \\
WIU $^{\mathrm{z}}$ & Canola & $226 \mathrm{ab}$ & $153 \mathrm{ab}$ & $407 \mathrm{ab}$ \\
& Fallow & $1,836 \mathrm{c}$ & $367 \mathrm{~b}$ & $2,618 \mathrm{~b}$ \\
& Mustard & $679 \mathrm{bc}$ & $73 \mathrm{ab}$ & $2,640 \mathrm{~b}$ \\
& Rapeseed & $459 \mathrm{bc}$ & $9 \mathrm{~b}$ & $204 \mathrm{a}$ \\
& Cereal rye & $205 \mathrm{ab}$ & $101 \mathrm{ab}$ & $2,087 \mathrm{ab}$ \\
& Cereal rye no-till & $58 \mathrm{a}$ & $\mathrm{ND}$ & $\mathrm{ND}$ \\
\multirow{3}{*}{ Hunt } & Fallow & 16 & $207 \mathrm{~b}$ & 0 \\
& Rapeseed & 19 & $48 \mathrm{a}$ & 0 \\
& Cereal rye & 7 & $48 \mathrm{a}$ & 0 \\
\hline
\end{tabular}

${ }^{w}$ Means followed by the same letter are not significantly based on the multiple comparison test with Tukey's adjustment method at $\alpha=0.05$. ND: no data were collected.

${ }^{x}$ Field trial at University of Illinois, Urbana-Champaign.

y Rapeseed did not overwinter in the Ayres field trials in 2012 and 2013, so soil was not collected from the rapeseed plots in those years.

z Field trial at Western Illinois University Allison Farm. In 2012 and 2013, the cereal rye no-till treatment was not planted at the WIU location. fallow plots (885 eggs) (Table 6). Similarly, 2011 results from the WIU site, showed the lowest nematode egg counts in the cereal rye no-till (58 eggs), rye (205 eggs), and canola plots (226 eggs); the counts in the no-till rye plots were significantly lower than those in the fallow $(1,836$ eggs) and mustard (679 eggs) plots. The WIU results for 2012 and 2013 were similar to those of 2011; lower nematode egg counts were detected in the canola, rapeseed, and cereal rye plots (Table 6).

Soybean yield. In most years and locations, no significant differences in soybean yield were observed (insignificant data not shown). The effect of cover crops on improving soybean yield in artificially inoculated field plots (UIUC) and naturally infested field plots (WIU and Hunt) was observed (Fig. 2B). In 2011, R. solani infestation caused significant yield reduction in the UIUC field trial $(P<$ 0.0001 ), and the average yield in the $R$. solani inoculated plots was significantly lower than the yield in the noninoculated plots (Fig. 2A). However, within the $R$. solani inoculated plots, the yield levels in the cereal rye treated plots were almost the same as the levels in the noninoculated plots (Fig. 2B), which was significantly more than that in the inoculated fallow and mustard plots (Fig. 2B). In the 2011 WIU field trial, the highest yields were in the no-till cereal rye treated plots, and in the 2013 Hunt field trial (all no-till), soybean yield was significantly higher in the rapeseed plots than the cereal rye plots (Fig. 2B).

Pathogens quantification in soil using qPCR. DNA of $H$. glycines and $P$. sojae were not detected using the qPCR assay in the soils collected from any location in either 2011 or 2012. The other four soilborne pathogens (C. truncatum, M. phaseolina, C. gregata, and $F$. virguliforme) were detected in all of the soils tested. However, there were no significant differences in pathogen populations associated with cover crop treatments for any of the four pathogens detected at any location in any year (Supplementary Table S1).

ANOVA of bacterial and fungal OTU richness resulting from cover crop treatments. Species richness is a measure of the total number of different species in an ecological community (Gotelli and Colwell 2001). ARISA profiles of amplicons generated by PCR of bacterial and fungal ITS sequences across the 172 samples from four farms through the three years yielded 337 bacterial OTUs and 193 fungal OTUs, and the ANOVA for OTU numbers showed that there were no significant differences in bacterial and fungal OTU numbers associated with different cover crop treatments at any of the trial locations in any of the three years (Supplementary

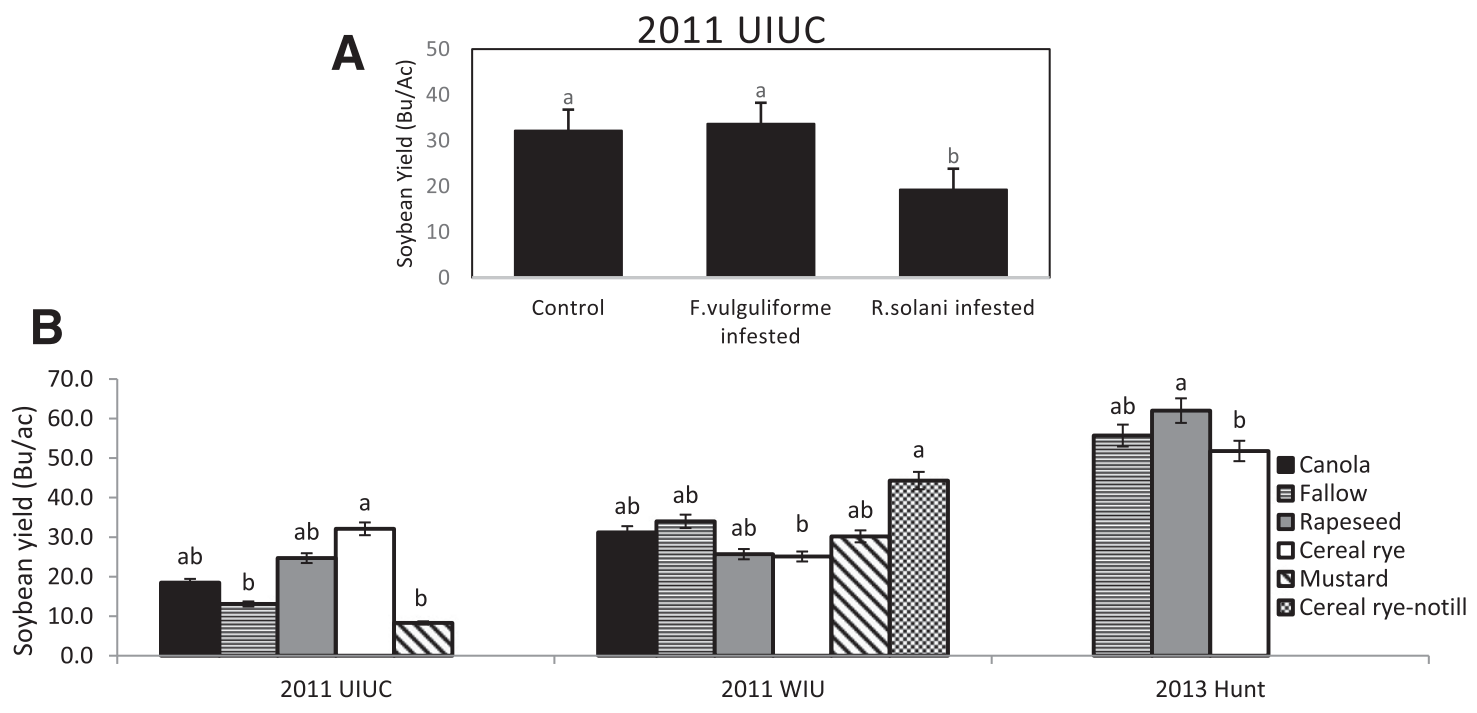

Fig. 2. Soybean yield in different pathogen inoculated plots with a cereal rye cover crop on the University of Illinois, Urbana-Champaign farm (UIUC) in 2011 (A), and soybean yield levels in different cover crop plots at UIUC in 2011, Western Illinois University (WIU) Allison Farm in 2011, and the Hunt Farm in 2013 (B). A, Soybean yield in different pathogen inoculated plots on the UIUC farm in 2011, followed by the same letter, were not significantly different based on the multiple comparison test with Tukey's adjustment method at $\alpha=$ 0.05. B, Soybean yield levels in different cover crop plots on the UIUC farm in 2011, WIU farm in 2011, and Hunt farm in 2013. The UIUC farm was inoculated artificially with two pathogens: Fusarium virguliforme and Rhizoctonia solani; data listed in the figure is a comparison of yield among different cover crop plots inoculated with $R$. solani. The WIU (incorporated) and Hunt (no-till) farms are naturally inoculated field plots. 
Table S2). Nonmetric multidimensional scaling (NMDS) was used to compare fingerprinting patterns among samples and to visualize dissimilarity between samples. NMDS plots indicated that location had a consistent effect on bacterial and fungal community structures (Fig.
3 ), and that bacterial and fungal community structures showed clear discrimination among the four farms, which indicated that bacterial and fungal community structures were significantly different over locations in all the three years. The ANOSIM procedure confirmed the

A

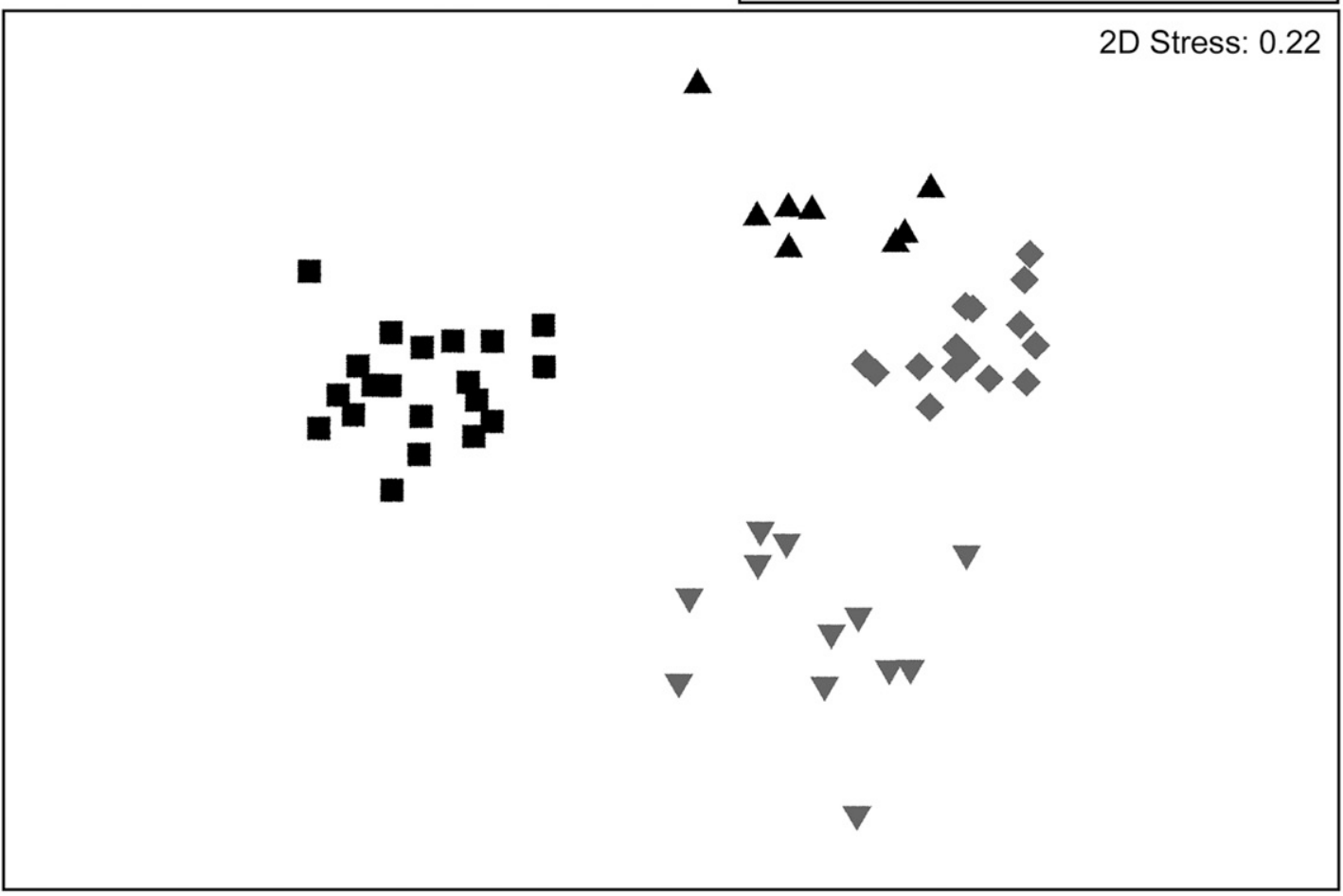

\begin{tabular}{|l|}
\hline Locations \\
\hline Ayres \\
$\nabla$ Hunt \\
a UIUC \\
- WIU \\
\hline
\end{tabular}

B

Standardise Samples by Total

Resemblance: S17 Bray Curtis similarity

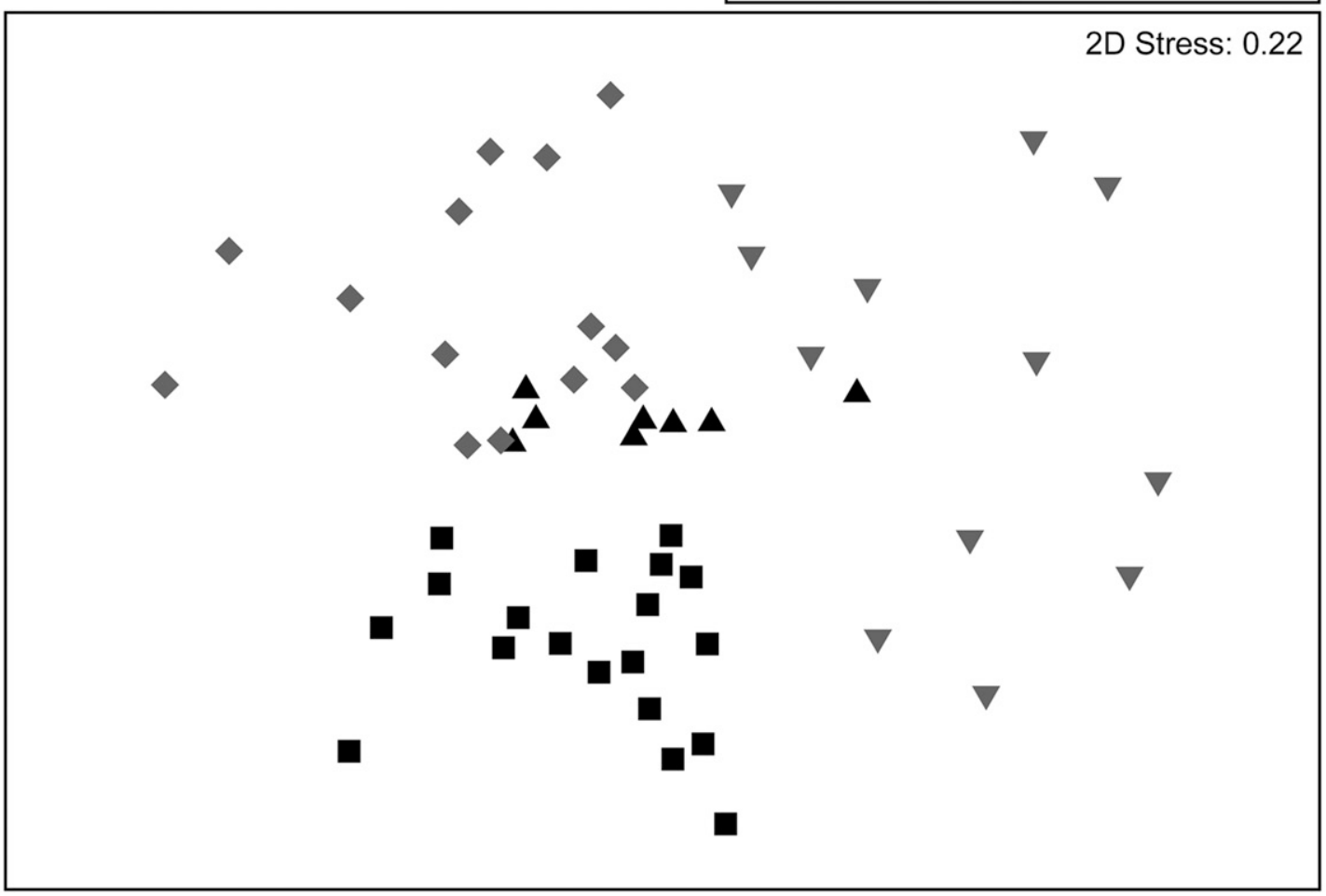

Fig. 3. Nonmetric multidimensional scaling (NMDS) plots for all ARISA profiles of soil samples collected from four Illinois locations from 2001 to 2013 . Triangles represent the Ayres Farm, inverted triangles represent the Hunt Farm, squares represent the University of Illinois, Urbana-Champaign (UIUC) farm, and diamonds represent the Western Illinois University (WIU) Allison farm. A, bacterial community structure; B, fungal community structure. 
result of the NMDS plots; bacterial community structures were significantly different among the four locations with global $R=0.97$, $P=0.001$ in 2011 and 2012, and global $R=0.98, P=0.001$ in 2013. Similarly, fungal community structures were significantly different among the four locations with global $R=0.482, P=0.001$ in $2011, R=0.462, P=0.001$ in 2012, and $R=0.491, P=0.001$ in 2013 (Table 7). In contrast, cover crop treatments had a smaller effect on changing microbial community structure, and bacterial and fungal community structures in different cover crop plots tended to distribute randomly in MDS plots, indicating that bacterial and fungal community structure were not significantly different among different cover crop plots. This result is consistent with the ANOSIM procedure result $(P<0.05$, insignificant data not shown), which shows that bacterial and fungal community structures were not significantly different among cover crop treatments at any of the four locations in any of the three years.

\section{Discussion}

Of the four cover crops evaluated in this study, cereal rye performed better overall when compared with the three Brassica cover crops. Cereal rye plots had better winter hardiness, and when soybeans were planted, they generally had lower severity of Rhizoctonia root rot and incidence of Septoria brown spot, reduced soybean cyst nematode populations, and improved populations and yields in $R$. solani infested soil. Rapeseed showed some effect on maintaining soybean plant populations, reducing Rhizoctonia root rot severity in the greenhouse, and reducing SCN egg counts. Canola significantly reduced SCN egg counts, but the results were not consistent over different locations and years. Mustard did not show any disease suppressing effect (except for a tendency to dramatically decrease SCN eggs compared with the fallow plot at the WIU site), but it also reduced soybean yield levels in some field trials.

Our results showed cereal rye reduced Rhizoctonia root rot, soybean cyst nematode population, and Septoria brown spot severities at certain locations, in some years. Other studies looking at the effect of cereal rye on crop yield have shown mixed results. It was found that cotton yield was increased by a rye cover crop (Raper et al. 2000). However, in another study by Wagger (1989), corn yield was decreased by a rye cover crop. Previous research has indicated that the yield decreases by rye may be the result of reduced nitrogen availability in addition to reduced crop emergence. Our results suggested that when soilborne diseases are severe, cereal rye shows the potential to significantly reduce disease severity, thus maintaining yield. In our study, the instances in which soybean yields were the lowest in the cereal rye treatments (at the WIU farm and Hunt farm), the plots were not artificially inoculated with pathogens and disease levels were low.

Brassica cover crops were reported to have significant biofumigant effects when incorporated into the soil. However, mixed results about the effects of cover crops to induce disease suppressiveness have been reported. Hansen and Keinath (2013) reported that radish, mustard, and rapeseed did not significantly reduce populations of $R$. solani, Pythium spp., or Sclerotium rolfsii compared with the control in green pepper fields. However increased yield of green pepper was observed. Hartz et al. (2005) suggested that a mustard green manure did not show an effect on suppressing diseases or improving tomato yields, which was consistent with the finding of our study. However, Himmelstein et al. (2014), showed that winter vetch (Vicia villosa) and crimson clover (Trifolium incarnatum) green manure significantly suppressed the incidence of Fusarium wilt of watermelon by as much as $21 \%$ compared with watermelon grown in nonamended plots. Larkin and Griffin (2007) found that Brassica green manures can significantly reduce a variety of soilborne potato pathogens including $R$. solani, Phytophthora erythroseptica, Pythium ultimum, Sclerotinia sclerotiorum, and Fusarium sambucinam.

In our study, the disease suppression effect varied among the three Brassica species. Rapeseed showed the most consistent positive effect of the three, including reducing Rhizoctonia root rot severity and nematode eggs, and increasing soybean yield. Significant allelopathic effects of rapeseed through a combination of mechanisms including bio-fumigation and manipulation of soil microbial structure have been reported in numerous studies (Halbrendt 1996; Larkin and Griffin 2007; Larkin and Honeycutt 2006; Larkin et al. 2010; Mazzola and Cohen 2005). In this study, significant reductions in SCN populations by rapeseed were observed at multiple locations and even in plots where rapeseed was established but did not overwinter (Hunt farm in 2012 and 2013, WIU and Ayres farm in 2011), which suggested that there might be higher concentration of glucosinolate in the roots than in the above ground portion of the rapeseed plant (Gardiner et al. 1999).

In this research, the lack of consistent effective disease suppression by the cover crops may have been the result of several factors including: poor seed germination poor winter hardiness, termination of cover crops by glyphosate prior to incorporation, lower glucosinolate concentrations due to no incorporation in no-till systems, extreme conversion of glucosinolates to ITCs hindered by weather conditions (too cold, too dry), and different levels of glucosinolate concentrations in different Brassica cover crops and species.

Mustard cover crops did not overwinter in 2011 and 2013 in the UIUC and WIU field trials, and rapeseed did not survive the second and third year in the Ayres and Hunt farm trials, which most likely affected the glucosinolate levels released into the soil. In addition, in our study, only the organic farm (WIU) terminated their cover crop by incorporating it into the soil; this was not the case at the other sites. At UIUC, cover crops were terminated before being incorporated in the soil, and Ayres and Hunt farms practiced no-till and did not incorporate the cover crop biomass, which may have affected the full release of glucosinolate. Larkin and Halloran (2014) compared the effect of different management practices of cover crops on suppressing potato disease and yield. The greatest effect was observed when cover crops were used as green manure, and some reduced positive effects were detected when cover crops were harvested then incorporated, and minimum effect was observed when cover crops were not incorporated into the soil (Larkin and Halloran 2014).

Table 7. Analysis of similarity (ANOSIM) statistics for bacterial and fungal community structure composition tests of all four Illinois locations from 2011 to 2013

\begin{tabular}{|c|c|c|c|c|c|c|c|c|c|c|c|c|}
\hline \multirow[b]{3}{*}{ Comparison } & \multicolumn{4}{|c|}{2011 ANOSIM } & \multicolumn{4}{|c|}{2012 ANOSIM } & \multicolumn{4}{|c|}{2013 ANOSIM } \\
\hline & \multicolumn{2}{|c|}{ Bacterial } & \multicolumn{2}{|c|}{ Fungal } & \multicolumn{2}{|c|}{ Bacterial } & \multicolumn{2}{|c|}{ Fungal } & \multicolumn{2}{|c|}{ Bacterial } & \multicolumn{2}{|c|}{ Fungal } \\
\hline & $R^{\mathbf{x}}$ & $P^{x}$ & $R$ & $P$ & $R$ & $P$ & $R$ & $P$ & $R$ & $P$ & $\boldsymbol{R}$ & $P$ \\
\hline Global & 0.97 & 0.001 & 0.482 & 0.001 & 0.97 & 0.001 & 0.462 & 0.001 & 0.98 & 0.001 & 0.491 & 0.001 \\
\hline Ayres versus Hunt & 0.538 & 0.001 & 0.08 & 0.041 & 0.907 & 0.001 & 0.213 & 0.017 & 0.905 & 0.001 & 0.312 & 0.001 \\
\hline Ayres versus UIUC & 0.997 & 0.001 & 0.497 & 0.001 & 0.999 & 0.001 & 0.386 & 0.001 & 0.945 & 0.001 & 0.354 & 0.001 \\
\hline Ayres versus WIUz & 0.982 & 0.001 & 0.481 & 0.001 & 0.962 & 0.001 & 0.115 & 0.098 & 0.954 & 0.001 & 0.264 & 0.002 \\
\hline Hunt versus UIUC & 0.994 & 0.001 & 0.495 & 0.001 & 0.988 & 0.001 & 0.617 & 0.001 & 0.975 & 0.001 & 0.546 & 0.001 \\
\hline Hunt versus WIU & 0.94 & 0.001 & 0.525 & 0.001 & 0.915 & 0.001 & 0.661 & 0.001 & 0.951 & 0.001 & 0.469 & 0.001 \\
\hline UIUC versus WIU & 1 & 0.001 & 0.672 & 0.001 & 1 & 0.001 & 0.54 & 0.001 & 1 & 0.001 & 0.469 & 0.001 \\
\hline
\end{tabular}

${ }^{\mathrm{x}} \mathrm{R}$ is scaled 0 to 1 , a value of zero representing the null hypothesis (indistinguishable), and a value of one representing all similarities within groups are less than any similarity between groups. $P$ value indicates significance level.

y Field trial at University of Illinois, Urbana-Champaign.

${ }^{\mathrm{z}}$ Field trial at Western Illinois University Allison Farm. 
Extreme weather conditions (extreme cold in Champaign County in the winters of 2011 and 2012, and extremely dry conditions in the fall) might be another adverse factor that affected the production, accumulation, or conversion of glucosinolates in cover crops. There is a wide genotypic variation in glucosinolate concentration among mustard and canola cultivars (Kirkegaard and Sarwar 1998). Therefore, more careful selection of cover crop genotypes with higher concentrations of glucosinolate may be needed.

Both enhancement of a specific antagonistic component in the soil (specific soil suppressiveness) and a soil microbial community structure shift (general soil suppressiveness) due to the addition of cover crops have been reported (De La Fuente et al. 2006; Larkin et al. 2010, 2017; Weller et al. 2002; Wiggins and Kinkel 2005a, b). However, in this study, no significant differences in six pathogen populations resulting from cover crop treatment were observed, nor were changes in microbial community structures resulting from cover crop treatments observed.

The soil microbial populations and community structure are influenced by a wide variety of factors. Besides cover cropping, soil type and texture (Buyer et al. 2002), soil moisture (Williams et al. 2006), $\mathrm{pH}$ (Fierer and Jackson 2006), and temperature have also been shown to affect soil microbial community composition, and those factors may become the constraint for microbial community composition change. In addition, most studies detecting a positive effect from cover crops and a change in the microbial community structure used cover crops as green manure, while our study generally terminated cover crops before incorporation, which may have resulted in our failure to detect a microbial community structural change.

Our study also highlighted the limitations of short-term cover crop treatments. The field locations were different each year at each study site, except for the Hunt Farm site that had cover crops in the same field location in the first and third years. The other study site locations only had the cover crop treatments in place for one fall to spring period. Significant effects of decreasing pathogen populations in the soil and changing microbial community structure may require longer periods of cover cropping to become apparent.

Overall, in a short time of cover cropping, general soil suppressiveness induced by cover crops was observed in our study, and cover crops provided some disease management in soybean fields. Under representative field conditions in the Midwestern U.S.A., cereal rye lowered the severity of Rhizoctonia root rot and incidence of Septoria brown spot, reduced SCN egg populations, and improved soybean populations and yields in $R$. solani infested soils. Rapeseed improved soybean plant populations in $R$. solani-inoculated soils, lowered Rhizoctonia root rot severity in the greenhouse experiment, and reduced SCN egg counts. Canola reduced SCN egg counts, but the results were not consistent over different locations and years. Mustard dramatically decreased SCN eggs compared with the fallow plot at only one location one time, but no other disease suppressive effects of mustard were observed, and mustard also reduced soybean yield levels in some field trials. Disease suppression is not the only potential benefit of using cover crops in an agronomic system. It has been documented that cereal rye and brassica cover crops play a significant role in reducing soil erosion and water runoff, and improving soil structure and water infiltration (Dabney et al. 2001; Miyao and Robins 2000). Therefore, it is possible that with repeated use of cover cropping over a longer period of time, more distinct effects on suppressing soybean diseases and a buildup in the beneficial properties of the soil may be achieved.

\section{Acknowledgments}

This study was funded by an NCR-SARE grant. We thank Sarah Anderson, Andy Clayton, Lance Coers, Brandt Hennes, John Hibbert, and Michael Ribbing for helping with soil collection, stand count, and disease rating at Allison and Hunt farms. We also thank Roger Bowen, Jeff Hansen, Charles Kusk, and Nan Jiang for helping with field work including planting cover crops and soybean, harvesting soybean, and herbicide application at the UIUC and Ayres locations. Without this help, this study could not have been completed.

\section{Literature Cited}

Anderson, I. C., and Cairney, J. W. G. 2004. Diversity and ecology of soil fungal communities: increased understanding through the application of molecular techniques. Appl. Environ. Microbiol. 6:769-779.
Bastian, F., Bouziri, L., Nicolardot, B., and Ranjard, L. 2009. Impact of wheat straw decomposition on successional patterns of soil microbial community structure. Soil Biol. Biochem. 41:262-275.

Bangarwa, S. K., Norsworthy, J. K., Mattice, J. D., and Gbur, E. E. 2011 Glucosinolate and isothiocyanate production from brassicaceae cover crops in a plasticulture production system. Weed Sci. 59:247-254.

Benítez, M. S., Tustas, F. B., Rotenberg, D., Kleinhenz, M. D., Cardina, J., Stinner, D. Miller, S. A., and Gardener, B. B. M. 2007. Multiple statistical approaches of community fingerprint data reveal bacterial populations associated with general disease suppression arising from the application of different organic field management strategies. Soil Biol. Biochem. 39:2289-2301.

Bugg, R. L., and Dutcher, J. D. 1989. Warm-season cover crop for pecan orchards: Horticultural and entomological implications. Biol. Agric. Hortic. 6:123-148.

Buskov, S., Serra, B., Rosa, E., Sørensen, H., and Sørensen, J. C. 2002. Effects of intact glucosinolates and products produced from glucosinolates in myrosinasecatalyzed hydrolysis on the potato cyst nematode (Globodera rostochiensis cv. Woll). Agric. Food Chem. 50:690-695.

Buyer, J. S., Roberts, D. P., and Russek-Cohen, E. 2002. Soil and plant effects on microbial community structure. Can. J. Microbiol. 48:955-964.

Buyer, J. S., Teasdale, J. R., Roberts, D. P., Zasada, I. A., and Maul, J. E. 2010. Factors affecting soil microbial community structure in tomato cropping systems. Soil Biol. Biochem. 42:831-841.

Carrera, L. M., Buyer, J. S., Vinyard, B., Abdul-Baki, A. A., Sikora, L. J., and Teasdale, J. R. 2007. Effects of cover crops, compost, and manure amendments on soil microbial community structure in tomato production systems. Appl. Soil Ecol. 37:247-255.

Curto, G., Dallavalle, E., Matteo, R., and Lazzeri, L. 2016. Biofumigant effect of new defatted seed meals against the southern root-knot nematode, Meloidogyne incognita. Ann. Appl. Biol. 169:17-26.

Dabney, S. M., Delgado, J. A., and Reeves, D. W. 2001. Using winter cover crops to improve soil and water quality. Commun. Soil Sci. Plant Anal. 32:1221-1250.

Danovaro, R., Luna, G. M., Dell'Anno, A., and Pietrangeli, B. 2006. Comparison of two fingerprinting techniques, terminal restriction fragment length polymorphism and automated ribosomal intergenic spacer analysis, for determination of bacterial diversity in aquatic environments. Appl. Environ. Microbiol. 72:59825989.

Davis, A. S. 2010. Cover-crop roller-crimper contributes to weed management in no-till soybean. Weed Sci. 58:300-309.

De La Fuente, L., Landa, B. B., and Weller, D. M. 2006. Host crop affects rhizosphere colonization and competetiveness 2,4-diacetylphloroglucinolproducing Pseudomonas fluorescens. Phytopathology 96:751-762.

De Nicola, G. R., Bagatta, M., Pagnotta, E., Angelino, D., Gennari, L., Ninfali, P., Rollin, P., and Iori, R. 2013. Comparison of bioactive phytochemical content and release of isothiocyanates in selected brassica sprouts. Food Chem. 141: 297-303.

Earl Creech, J., Westphal, A., Ferris, V. R., Faghihi, J., Vyn, T. J., Santini, J. B., and Johnson, W. G. 2008. Influence of winter annual weed management and crop rotation on soybean cyst nematode (Heterodera glycines) and winter annual weeds. Weed Sci. 56:103-111.

Fierer, N., and Jackson, R. B. 2006. The diversity and biogeography of soil bacterial communities. Proc. Natl. Acad. Sci. USA 103:626-631.

Fisher, M. M., and Triplett, E. W. 1999. Automated approach for ribosomal intergenic spacer analysis of microbial diversity and its application to freshwater bacterial communities. Appl. Environ. Microbiol. 65:4630-4636.

Frasier, I., Noellemeyer, E., Figuerola, E., Erijman, L., Permingeat, H., and Quiroga, A. 2016. High quality residues from cover crops favor changes in microbial community and enhance $\mathrm{C}$ and $\mathrm{N}$ sequestration. Glob. Ecol. Conserv. 6:242-256.

Gotelli, N. J., and Colwell, R. K. 2001. Quantifying biodiversity: procedures and pitfalls in the measurement and comparison of species richness. Ecol. Lett. 4: 379-391.

Gardiner, J. B., Morra, M. J., Eberlein, C. V., Brown, P. D., and Borek, V. 1999 Allelochemicals released in soil following incorporation of rapeseed (Brassica napus) green manures. J. Agric. Food Chem. 47:3837-3842.

Gómez, J. A., Llewellyn, C., Basch, G., Sutton, P. B., Dyson, J. S., and Jones, C. A. 2011. The effects of cover crops and conventional tillage on soil and runoff loss in vineyards and olive groves in several Mediterranean countries. Soil Use Manage. 27:502-514.

Halbrendt, J. M. 1996. Allelopathy in the management of plant-parasitic nematodes. J. Nematol. 28:8-14.

Hansen, Z. R., and Keinath, A. P. 2013. Increased pepper yields following incorporation of biofumigation cover crops and the effects on soilborne pathogen populations and pepper diseases. Appl. Soil Ecol. 63:67-77.

Haramoto, E. R., and Gallandt, E. R. 2004. Brassica cover cropping for weed management: A review. Renew. Agric. Food Syst. 19:187-198.

Hartman, G. L., Rupe, J. C., Sikora, E. J., Domier, L. L., Davis, J. A., and Steffey, K. L. 2015. Compendium of Soybean Diseases and Pests. Fifth Edition. APS Press, St. Paul, MN.

Hartz, T. K., Johnstone, P. R., Miyao, E. M., and Davis, R. M. 2005. Mustard cover crops are ineffective in suppressing soilborne disease or improving processing tomato yield. HortScience 40:2016-2019.

Haudenshield, J. S., Bowen, C. R., and Hartman, G. L. 2012. Pentaplex Q-PCR quantifies DNA from fungi causing anthracnose, brown stem rot, and charcoal rot in field samples of soybean. Poster 335-P. Phytopathology 102:51. 
Haudenshield, J. S., Song, J., and Hartman, G. L. 2017. A novel multiplexed, probe-based quantitative PCR assay for the soybean root-rot pathogen Phytophthora sojae utilizes its transposable element. PLoS One 12:e0176567.

Himmelstein, J. C., Maul, J. E., and Everts, K. L. 2014. Impact of five cover crop green manures and actinovate on Fusarium wilt of watermelon. Plant Dis. 98:965-972.

Hoyt, G. D. 1999. Tillage and cover residue effects on vegetable yields. HortTechnology 9:351-358.

Huang, Y. H., and Hartman, G. L. 1998. Reaction of selected soybean genotypes to isolates of Fusarium solani f. sp. glycines and their culture filtrates. Plant Dis. 82:999-1002.

Jami, E., Shterzer, N., and Mizrahi, I. 2014. Evaluation of automated ribosomal intergenic spacer analysis for bacterial fingerprinting of rumen microbiome compared to pyrosequencing technology. Pathogens 3:109-120.

Ji, P., Koné, D., Yin, J., Jackson, K. L., and Csinos, A. S. 2012. Soil amendments with Brassica cover crops for management of Phytophthora blight on squash. Pest Manag. Sci. 68:639-644.

Kaspar, T. C., Jaynes, D. B., Parkin, T. B., and Moorman, T. B. 2007. Rye cover crop and gamagrass strip effects on $\mathrm{NO}_{3}$ concentration and load in tile drainage. J. Environ. Qual. 36:1503-1511.

Kennedy, N., Brodie, E., Connolly, J., and Clipson, N. 2006. Seasonal influences on fungal community structure in unimproved and improved upland grassland soils. Can. J. Microbiol. 52:689-694.

Kent, A. D., Yannarell, A. C., Rusak, J. A., Triplett, E. W., and McMahon, K. D. 2007. Synchrony in aquatic microbial community dynamics. ISME J. 1:38-47.

Kirkegaard, J. A., and Sarwar, M. 1998. Biofumigation potential of brassicas. Plant Soil 201:71-89.

Krishnan, G., Holshouser, D. L., and Nissen, S. J. 1998. Weed control in soybean (Glycine max) with green manure crops. Weed Technol. 12:97-102.

Koenning, S. R., and Wrather, J. A. 2010. Suppression of soybean yield potential in the continental United States by plant diseases from 2006 to 2009. Plant Health Prog. doi:10.1094/PHP-2010-1122-01-RS

Lambert, K. N., Bekal, S., Domier, L. L., Niblack, T. L., Noel, G. R., and Smyth, C. A. 2005. Selection of Heterodera glycines chorismate mutase-1 alleles on nematode-resistant soybean. Mol. Plant-Microbe Interact. 18:593-601.

Larkin, R. P., and Griffin, T. S. 2007. Control of soilborne diseases of potato using Brassica green manures. Crop Prot. 26:1067-1077.

Larkin, R. P., Griffin, T. S., and Honeycutt, C. W. 2010. Rotation and cover crop effects on soilborne potato diseases, tuber yield, and soil microbial communities. Plant Dis. 94:1491-1502.

Larkin, R. P., and Halloran, J. M. 2014. Management effects of diseasesuppressive rotation crops on potato yield and soilborne disease and their economic implications in potato production. Am. J. Potato Res. 91:429-439.

Larkin, R. P., and Honeycutt, C. W. 2006. Effects of different 3-year cropping systems on soil microbial communities and rhizoctonia diseases of potato. Phytopathology 96:68-79.

Larkin, R. P., Honeycutt, C. W., Griffin, T. S., Olanya, O. M., He, Z., and Halloran, J. M. 2017. Cumulative and residual effects of different potato cropping system management strategies on soilborne diseases and soil microbial communities over time. Plant Pathol. J. 66:437-449.

Li, S., Hartman, G. L., Domier, L. L., and Boykin, D. 2008. Quantification of Fusarium solani f. sp. glycines isolates in soybean roots by colony-forming unit assays and real-time quantitative PCR. Theor. Appl. Genet. 117:343-352.

Liu, Z., and Sinclair, J. B. 1991. Isolates of Rhizoctonia solani anastomosis group 2-2 pathogenic to soybean. Plant Dis. 75:682-687.

Malvick, D. K., and Impullitti, A. E. 2007. Detection and quantification of Phialophora gregata in soybean and soil samples with a quantitative, realtime PCR assay. Plant Dis. 91:736-742.

Marzano, S., Villamil, M. B., Wander, M. M., Ugarte, C. M., Wen, L., and Eastburn, D. M. 2015. Organic transition effects on soilborne diseases of soybean and populations of Pseudomonadaceae. J. Am. Soc. Agron. 107:1087-1097.

Masiunas, J. B., Weston, L. A., and Weller, S. C. 1995. The impact of rye cover crops on weed populations in tomato cropping systems. Weed Sci. 43: 318-323.

Mazzola, M., and Cohen, M. F. 2005. Suppression of Rhizoctonia root rot by Streptomyces in Brassica seed meal-amended soil. In: Annual International Research Conference on Methyl Bromide Alternatives and Emissions Reductions. MBAO, Fresno, CA.
Mazzoncini, M., Sapkota, T. B., Bàrberi, P., Antichi, D., and Risaliti, R. 2011. Longterm effect of tillage, nitrogen fertilization and cover crops on soil organic carbon and total nitrogen content. Soil Tillage Res. 114:165-174.

Mbuthia, L. W., Acosta-Martínez, V., Debryun, J., Schaeffer, S., Tyler, D., Odoi, E., Mpheshea, M., Walker, F., and Eash, N. 2015. Long-term tillage, cover crop, and fertilization effects on microbial community structure, activity: Implications for soil quality. Soil Biol. Biochem. 89:24-34.

Melgar, J., Roy, K. W., and Abney, T. S. 1994. Sudden death syndrome of soybean: etiology, symptomatology, and effects of irrigation and Heterodera glycines on incidence and severity under field conditions. Can. J. Bot. 72:1647-1653.

Mirsky, S. B., Curran, W. S., Mortenseny, D. M., Ryany, M. R., and Shumway, D. L. 2011. Timing of cover-crop management effects on weed suppression in No-Till planted soybean using a roller-crimper. Weed Sci. 59:380-389.

Miyao, G., and Robins, P. 2000. Influence of fall-planted cover crops on rainfall run-off in a processing tomato production system. Acta Hortic. 542:343-346.

Moore, M. J., Gillespie, T. J., and Swanton, C. J. 1994. Effect of cover crop mulches on weed emergence, weed biomass, and soybean (Glycine max) development. Weed Technol. 8:512-518.

Mowlick, S., Yasukawa, H., Inoue, T., Takehara, T., Kaku, N., Ueki, K., and Ueki, A. 2013. Suppression of spinach wilt disease by biological soil disinfestation incorporated with Brassica juncea plants in association with changes in soil bacterial communities. Crop Prot. 54:185-193.

Nascente, A. S., Li, Y. C., and Crusciol, C. A. C. 2013. Cover crops and No-Till effects on physical fractions of soil organic matter. Soil Tillage Res. 130:52-57.

Niblack, T. L., Heinz, R. D., Smith, G. S., and Donald, P. A. 1993. Distribution, density, and diversity of Heterodera glycines in Missouri. J. Nematol. 25:880-886.

Raper, R. L., Reeves, D. W., Burmester, C. H., and Schwab, E. B. 2000. Tillage depth, tillage timing, and cover crop effects on cotton yield, soil strength, and tillage energy requirements. Appl. Eng. Agric. 16:379-385.

Riga, E., Topp, E., Potter, J., Welacky, T., Anderson, T., and Tenuta, A. 2001. The impact of plant residues on the soybean cyst nematode, Heterodera glycines. Can. J. Plant Pathol. 23:168-173.

Ristaino, J. B., Parra, G., and Campbell, C. L. 1997. Suppression of phytophthora blight in bell pepper by a no-till wheat cover crop. Phytopathology 87:242-249.

Rudolph, R. E., Sams, C., Steiner, R., Thomas, S. H., Walker, S., and Uchanski, M. E. 2015. Biofumigation performance of four brassica crops in a green chile pepper (Capsicum annuum) rotation system in southern New Mexico. HortScience 50:247-253.

Spencer, M. D., Hamp, T. J., Reid, R. W., Fischer, L. M., Zeisel, S. H., and Fodor, A. A. 2011. Association between composition of the human gastrointestina microbiome and development of fatty liver with choline deficiency. Gastroenterology 140:976-986.

Szczygłowska, M., Piekarska, A., Konieczka, P., and Namieśnik, J. 2011. Use of Brassica plants in the phytoremediation and biofumigation processes. Int. J. Mol. Sci. 12:7760-7771.

Villamil, M. B., Bollero, G. A., Darmody, R. G., Simmons, F. W., and Bullock, D. G. 2006. No-Till corn/soybean systems including winter cover crops. Soil Sci. Soc. Am. J. 70:1936-1944.

Wagger, M. G. 1989. Cover crop management and nitrogen rate in relation to growth and yield of No-Till corn. Agron. J. 81:533-538.

Wang, K.-H., Sipes, B. S., and Schmitt, D. P. 2001. Suppression of Rotylenchulus reniformis by Crotalaria juncea, Brassica napus, and Tagetes erecta. Nematropica 31:235-249.

Weller, D. M., Raaijmakers, J. M., Gardener, B. B. M., and Thomashow, L. S. 2002. Microbial populations responsible for specific soil suppressiveness to plant pathogens. Annu. Rev. Phytopathol. 40:309-348.

Williams, M. A., Myrold, D. D., and Bottomley, P. J. 2006. Carbon flow from 13Clabeled straw and root residues into the phospholipid fatty acids of a soil microbial community under field conditions. Soil Biol. Biochem. 38:759-768.

Wiggins, B. E., and Kinkel, L. L. 2005a. Green manner and crop sequences influence alfalfa root rot pathogen inhibitory activity of indigenous Streptomycetes. Plant Soil 268:271-283.

Wiggins, B. E., and Kinkel, L. L. 2005b. Green manner and crop sequences influence potato diseases and pathogen inhibitory activity of indigenous Streptomycetes. Phytopathology 95:178-185.

Yannarell, A. C., and Triplett, E. W. 2005. Geographic and environmental sources of variation in lake bacterial community composition. Appl. Environ. Microbiol 71:227-239. 